\title{
TREATMENT OF OSTEO-ARTHRITIS OF THE KNEES
}

\author{
BY \\ V. WRIGHT \\ From the Rheumatism Research Unit, University Department of Medicine, the General Infirmary at Leeds, \\ and the Royal Bath Hospital, Harrogate.
}

Relatively little has been published about the treatment of osteo-arthritis. Therapy consists mainly of analgesic drugs and local measures such as intra-articular corticosteroids and short-wave diathermy. Few controlled trials have been done and it is difficult to evaluate some reports owing to lack of distinction of response in patients with rheumatoid arthritis and those with osteo-arthritis (Hollander, Brown, Jessar, and Brown, 1951; Duff, 1956; Zuckner, Machek, and Ahern, 1956; Bonner, 1959).

In a study of the value of intra-articular therapy in rheumatic diseases, we have shown that in rheumatoid arthritis intra-articular injections of hydrocortisone acetate and hydrocortisone tertiary butyl acetate produce improvement in pain, tenderness, walking time, range of movement, and limitation of extension (Chandler, Wright, and Hartfall, 1958). In contrast, a trial of these two drugs in osteoarthritis, conducted under exactly similar conditions, showed only a transient relief of pain (Wright, Chandler, Morison, and Hartfall, 1960). It was noted, moreover, that with 33 per cent. of patients there was improvement from the injection of inert material, and this interesting problem formed the basis of a further study by Morison, Woodmansey, and Young (1961).

The present controlled study was designed there- fore to ascertain the relative value of courses of placebo tablets, placebo injections, and short-wave diathermy in the treatment of osteo-arthritis.

\section{Design of Trial}

38 patients whose main complaint arose from osteo-arthritis of the knees were included in the trial. In 21 both knees were treated and in seventeen only one knee, giving a total of 59 joints. No patients had received intra-articular therapy or short-wave diathermy within 6 months of the start of the trial. The study was conducted in an out-patient department.

One of three courses of treatment was randomly allocated to each patient from a previously prepared master sheet. Each course lasted 6 weeks.

(1) Those receiving placebo tablets took one tablet twice daily.

(2) Those receiving intra-articular therapy received four fortnightly injections of $2 \mathrm{ml}$. normal saline into the knees.

(3) Short-wave diathermy was given for 20 minutes three times a week for 6 weeks.

Particulars of the patients in each group are shown in Table I.

TABLE I

COMPARISON OF TREATMENT GROUPS AT START OF TRIAL

\begin{tabular}{|c|c|c|c|c|c|c|c|c|}
\hline \multirow{2}{*}{ Treatment Group } & & \multicolumn{4}{|c|}{ Patients } & \multicolumn{3}{|c|}{ Arthritic Status } \\
\hline & & Total & Males & No. of Joints & $\underset{(y r s)}{\text { Mean Age }}$ & Mean Pain* & $\begin{array}{c}\text { Mean } \\
\text { Tenderness* }\end{array}$ & $\begin{array}{l}\text { Mean Walking } \\
\text { Time (sec.) }\end{array}$ \\
\hline Placebo Tablets & $\cdots$ & 13 & - & 19 & $60 \cdot 5$ & $3 \cdot 5$ & $1 \cdot 6$ & 103 \\
\hline Placebo Injections $\quad \ldots$ & $\cdots$ & 12 & 2 & 18 & $61 \cdot 1$ & $3 \cdot 3$ & $1 \cdot 3$ & 98 \\
\hline Short-wave Diathermy & . & 13 & 1 & 22 & $65 \cdot 2$ & $3 \cdot 0$ & $1 \cdot 7$ & 111 \\
\hline Total & $\cdots$ & 38 & 3 & 59 & $62 \cdot 2$ & & & \\
\hline
\end{tabular}

- See text for grades. 
Assessments were made immediately before the start of the trial and at fortnightly intervals after a course of treatment for a maximum of 26 weeks from the start of trial. The following measurements were recorded:

Walking time over 75 yards

Tenderness $0=$ absent

$1=$ slight

$2=$ moderate

$3=$ wincing

$4=$ withdrawal and/or exclamation.

Pain

$0=$ none

$1=$ slight on walking

$2=$ marked on walking

$3=$ mild at rest

$4=$ severe at rest.

Number of analgesic tablets taken daily.

\section{Results}

One patient receiving short-wave diathermy was withdrawn from the trial because her family doctor changed her drug therapy to deltabutazolidin.

At each assessment a patient was considered to have improved if two of the four parameters showed improvement. It was found that patients either experienced no improvement, short improvement up to 4 weeks, or improvement for more than 10 weeks. Improvement was therefore graded as none, short or, long on this basis, and results are summarized in Table II. At the 6 months assessment, four patients treated with placebo tablets, four treated with placebo injections, and six treated with short-wave diathermy had maintained their improvement. No further assessments were made after this time, so that it was not possible to calculate the mean duration of improvement.

TABLE II

IMPROVEMENT AFTER COURSES OF TREATMENT

\begin{tabular}{|c|c|c|c|c|c|}
\hline \multirow{2}{*}{$\begin{array}{c}\text { Treatment } \\
\text { Group }\end{array}$} & \multicolumn{3}{|c|}{ Improvement } & \multirow{2}{*}{$\begin{array}{c}\text { No } \\
\text { Improvement }\end{array}$} & \multirow{2}{*}{$\begin{array}{l}\text { Total } \\
\text { No. of } \\
\text { Joints }\end{array}$} \\
\hline & Total & $\begin{array}{c}\text { Long } \\
\text { Duration }\end{array}$ & $\begin{array}{c}\text { Short } \\
\text { Duration }\end{array}$ & & \\
\hline $\begin{array}{l}\text { Placebo } \\
\text { Tablets }\end{array}$ & 4 & 4 & 一 & 15 & 19 \\
\hline $\begin{array}{l}\text { Placebo } \\
\text { Injections }\end{array}$ & 11 & 6 & 5 & 7 & 18 \\
\hline Short-wave & 14 & 11 & 3 & 6 & $20 *$ \\
\hline
\end{tabular}

* One patient omitted from Study.

More knees improved after a course of short-wave diathermy (14) than after a course of placebo tablets (5), a highly significant difference $(P<0.01)$.
Eleven knees improved after a course of placebo injections and this improvement compared with that on placebo tablets is probably significant $(P<0.05)$. There was no significant difference between improvement after short-wave diathermy and that on placebo injections $(P<0 \cdot 1)$.

More patients showed long-term improvement after short-wave diathermy (11) than after placebo injections (6) and placebo tablets (5), but this difference did not reach the level of significance $(\mathrm{P}<0 \cdot 1)$.

\section{Discussion}

These findings confirm our previous observations that a proportion of patients with osteo-arthritis will improve after the intra-articular injection of an inert substance or a course of pacebo tablets (Wright and others, 1960; Morison and others, 1961). Miller, White, and Norton (1958), in a careful study of the value of intra-articular injections in osteoarthritis of the knee, investigated 181 patients in five treatment groups receiving different series of five injections at fortnightly intervals:

(1) Lactic acid and procaine,

(2) Procaine,

(3) Physiological saline,

(4) Hydrocortisone,

(5) Nothing - a mock injection procedure being carried out.

They found that 84.5 per cent. of the patients in all groups reported subjective improvement 6 weeks after the course, which was confirmed by objective assessment in 84.7 per cent. of the men and 68 per cent. of the women. At 6 months 79.6 per cent. stated that they were improved. The design of their trial precluded assessment of short-term benefit. They obtained a higher percentage of improvement with placebo injections than we experienced, our figures for improvement maintained for more than 6 weeks with injections of physiological saline being 33 per cent. compared with their 80 per cent.

The findings in the present study are more in keeping with the usual incidence of placebo reactors (Lasagna, Mosteller von Felsinger, and Beecher, 1954; Joyce, 1959). The enhanced placebo effect of injections compared with tablets might be anticipated; the aseptic ritual accompanying intraarticular therapy can hardly fail to impress suggestible patients. Miller and others (1958) suggest that, if intra-articular injections for osteo-arthritis are chosen, the least noxious and most economical substance, such as normal saline or nothing (by mock injection), should be used.

The results of the present study indicate that significantly greater benefit was derived from a 
course of short-wave diathermy than from placebo tablets. More patients improved after short-wave diathermy than after intra-articular injections, and this was more noticeable in long-term improvement, but the differences did not achieve significance.

Although side-effects from intra-articular therapy are few in experienced hands, the treatment is not without danger. In the therapy of osteo-arthritis of the knees, therefore, when the choice lies between short-wave diathermy and intra-articular therapy, it would appear that short-wave diathermy should be given first. A comparison of these results with our previous findings (Wright and others, 1960) suggests that, for intra-articular therapy, physiological saline is likely to be as effective as hydrocortisone or its analogues.

\section{Summary}

The effect of courses of placebo tablets, intraarticular placebo injections, and short-wave diathermy has been studied in 38 patients with osteoarthritis whose main incapacity arose from involvement of the knees. Courses of treatment were randomly allocated and administered over a period of 6 weeks. Pain, tenderness, walking time, and number of analgesic tablets taken were assessed at the start of the trial and at fortnightly intervals after the course of treatment to a maximum of 6 months. Short-wave diathermy gave significantly better results than placebo tablets, and placebo injections also have greater improvement than placebo tablets (this was significant at the 5 per cent. level).

It is suggested that, of these treatments for osteoarthritis, short-wave diathermy is preferable as a first choice. If intra-articular therapy is indicated, comparison with previous results suggests that physiological saline is likely to confer as much benefit as hydrocortisone or its analogues.

I am indebted to Prof. S. J. Hartfall, who afforded facilities for this study, to Mr. N. W. Blacow, senior pharmacist, and Miss B. Knowles, physiotherapist, at the General Infirmary, Leeds, for their help, and to Miss B. Thewlis for secretarial assistance.

\section{REFERENCES}

Bonner, C. D. (1959). Arch. inter.-amer. Rheum., 2, 3. Chandler, G. N., Wright, V., and Hartfall, S. J. (1958). Lancet, 2, 659.

Duff, I. F. (1956). Postgrad. Med., 19, 577.

Hollander, J. L., Brown, E. M., Jr. Jessar, R. A., and Brown, C. Y. (1951). J. Amer. med. Ass., 147, 1629.
Joyce, C. R. B. (1959). Brit. J. Pharmacol., 14, 512.

Lasagna, L., Mosteller, F., von Felsinger, J. M., and Beecher, H. K. (1954). Amer.J. Med., 16, 770.

Miller, J. H., White, J., and Norton, T. H. (1958). J. Bone Jt Surg., 40B, 636.

Morison, R. A. H., Woodmansey, A., and Young, A. J. (1961). Ann. rheum. Dis., 20, 179.

Wright, V., Chandler, G. N., Morison, R. A. H., and Hartfall, S. J. (1960). Ibid., 19, 257.

Zuckner, J., Machek, O., and Ahern, A. M. (1956). Ibid., 15, 258.

\section{Traitement de l'ostéoarthrite du genou RÉSUMÉ}

On étudia l'effet des traitements par des comprimés inertes, des injections intra-articulaires d'une substance inerte et par la diathermie par ondes courtes chez 38 malades atteints d'ostéoarthrite, dont l'incapacité principale provenait des lésions aux genoux. Chaque traitement fut assigné au hasard et administré pendant une période de 6 semaines. La douleur, la sensibilité douloureuse, la durée de la marche et le nombre de comprimés analgésiques furent détermines au début de l'expérience et tous les quinze jours pendant un maximum de 6 mois. La diathermie par ondes courtes donna des résultats significativement meilleurs que les comprimés inertes; les injections d'une substance thérapeutiquement inerte donnèrent aussi des résultats meilleurs que les comprimés inertes (ceci était significatif dans les limites de cinq pour cent).

On pense que, de tous ces traitements de l'ostéoarthrite, la diathermie par ondes courtes l'emporte comme premier choix. Lorsque la thérapie intra-articulaire est indiquée, la comparaison des résultats cités semble montrer que l'eau physiologique fera autant du bien que l'hydrocortisone ou ses analogues.

\section{Tratamiento de la osteoartritis de la rodilla Sumario}

Se estudió el efecto de tratamientos con comprimidos terapéuticamente inertes, inyecciones intra-articulares terapéuticamente inertes y diatermia por ondas cortas en 38 enfermos con osteoartritis, cuya incapacidad principal provenía de las lesiones en las rodillas. Cada tratamiento fué asignado al azar y administrado durante un período de 6 semanas. El dolor, la sensibilidad dolorosa, el tiempo de andar y el número de comprimidos analgésicos fueron apreciados al principio de la investigación y luego cada dos semanas durante un máximo de 6 meses. La diatermia por ondas cortas dió resultados significativamente mejores que los comprimidos inertes; las inyecciones de substancia terapéuticamente inerte produjeron también más mejoría que los comprimidos inertes (esto fué estadísticamente significativo en los límites de 5 por ciento).

Se sugiere que de todos estos tratamientos de osteoartritis, la diatermia por ondas cortas es preferible. Cuando la terapia intra-articular se ve indicada, la comparación de los resultados citados sugiere que la solución salina fisiológica puede otorgar tanto beneficio como la hidrocortisona o sus análogos. 